\title{
Pengabdian KKN Mandiri Desa Raporendu Kecamatan Nangapanda Kabupaten Ende
}

\author{
Indah Wahyuning Tyas ${ }^{1 *}$, Aldi Ibrahim², Yohanes $\mathrm{Meo}^{3}$ \\ 1,2,3 Universitas Flores, Ende, Indonesia \\ *Corresponding Author: indahtyas86@gmail.com
}

\begin{abstract}
Info Artike1
Diterima : 19/01/2022

Direvisi: $21 / 01 / 2022$

Disetujui: $26 / 01 / 2022$

Abstract. The Independent Real Work Lecture (KKN) of the University of Flores in 2021 will be held on August $02-31,2021$. It has the theme, "Resilient Community in Facing Covid-19 with the University of Flores KKN" and the sub-theme "Management and Design of Village Facilities and Infrastructure/ Locally Based Villages". The location is carried out in Raporendu Village, Nangapanda District, Ende Regency, East Nusa Tenggara Province. This KKN activity is the result of the collaboration of the local village government, the community, students and Field Supervisors (DPL). The purpose of this activity is so that students can apply what they have learned in college, and get a learning experience by being directly involved with the community, through problems they find and finding solutions. There are several problems encountered at the location, so there needs to be a joint effort to reduce or overcome them. (1) the lack of supporting facilities to suppress the transmission of the Covid-19 virus in Raporendu Village, a sink or hand washing area is made in front of the Village Office for office employees or guests/local residents who come to visit, (2) Making garbage bins from brick material to overcome environmental pollution due to scattered garbage, (3) repairing electrical installations at ports, (4) making gates from local bamboo materials, (5) community service cleaning houses of worship and the village environment. The results of this activity are expected to provide benefits for the government and local communities, and can work together for KKN activities the following year.
\end{abstract}

Keywords: Independent Community Service, Raporendu Village, Sink, Trash Can, Community Service

\begin{abstract}
Abstrak. Kuliah Kerja Nyata (KKN) Mandiri Universitas Flores tahun 2021 di selenggarakan pada tanggal 231 Agustus 2021. Memiliki tema yaitu, "Masyarakat Tangguh Dalam Menghadapi Covid-19 Bersama KKN Universitas Flores" dan sub tema "Pengelolaan dan Perancangan Sarana dan Prasarana Desa/Kelurahan Berbasis Lokal". Lokasi di laksanakan di Desa Raporendu, Kecamatan Nangapanda, Kabupaten Ende, Provinsi Nusa Tenggara Timur. Kegiatan KKN ini hasil kerja sama pemerintah desa setempat, masyarakat, mahasiswa dan Dosen Pembimbing Lapangan (DPL). Tujuan kegiatan ini agar mahasiswa bisa menerapkan apa yang mereka peroleh dibangku kuliah, dan mendapat pengalaman belajar dengan ikut terlibat bersama masyarakat secara langsung, melalui masalah yang ditemukan dan mencari solusinya. Ada beberapa masalah yang dijumpai dilokasi, sehingga perlu adanya usaha bersama untuk mengurangi atau mengatasi hal tersebut. (1) minimnya fasilitas yang menunjang untuk menekan penularan virus Covid-19 di Desa Raporendu, maka dibuatkan wastafel atau tempat cuci tangan didepan Kantor Desa untuk pegawai kantor atau tamu/warga setempat yang datang berkunjung, (2) Pembuatan bak sampah dari bahan batako untuk mengatasi pencemaran lingkungan akibat sampah yang berserakan, (3) memperbaiki instalasi listrik di pelabuhan, (4) pembuatan gapura dari bahan bambu lokal, (5) kerja bakti membersihkan rumah ibadat dan lingkungan desa. Dari hasil kegiatan ini diharapkan dapat memberikan manfaat bagi pemerintah dan masyarakat setempat, dan dapat bekerja sama untuk kegiatan KKN tahun selanjutnya.
\end{abstract}

Kata Kunci: KKN Mandiri, Desa Raporendu, Wastafel, Bak Sampah, Kerja Bakti

How to Cite: Tyas, I. W., AIbrahim, A., \& Meo, Y. (2022). Pengabdian KKN Mandiri Desa Raporendu Kecamatan Nangapanda Kabupaten Ende. Prima Abdika: Jurnal Pengabdian Masyarakat, 2(1), 14-23. https://doi.org/10.37478/abdika.v2i1.1603

Copyright (c) 2022 Indah Wahyuning Tyas, Aldi Ibrahim, Yohanes Meo. This work is licensed under a Creative Commons Attribution-ShareAlike 4.0 International License.

\section{Pendahuluan}

Kuliah Kerja Nyata (KKN) adalah salah bentuk implementasi dari Tri Dharma Perguruan Tinggi yakni pengabdian masyarakat selain pengajaran dan penelitian. Mahasiswa dituntut memiliki kreativitas dan perilaku inovatif guna memenuhi ketiga hal tersebut. Pelaksanaan KKN Universitas Flores pada tahun 2021 dilakukan secara mandiri yaitu pada tanggal 02-31 Agustus 2021. Pandemi Covid-19 sudah melanda dunia selama 2 tahun, kasus penderita Covid-19 secara global dan lokal terus meningkat (Heydemans et al., 
2021). Dikarenakan masih dalam situasi pandemi, menyebabkan segala aktivitas menjadi berbeda dan terbatas termasuk kegiatan pengabdian masyarakat yakni Kuliah Kerja Nyata. KKN dilakukan secara mandiri di wilayah domisili masing-masing mahasiswa, namun masih berbentuk kelompok yang dibentuk secara mandiri oleh peserta (Umar et al., 2021). KKN bertujuan meningkatkan empati dan kepedulian mahasiswa terhadap lingkungan masyarakat, mampu bekerjasama dalam kelompok, bertanggug jawab, disiplin, dan memiliki etos kerja. Lokasi kegiatan KKN berada di Desa Raporendu, Kecamatan Nangapanda, Kabupaten Ende dengan luas wilayah $18,58 \mathrm{Km}^{2}$ dan berjarak sekitar $24 \mathrm{Km}$ dari Universitas Flores. Batas-batas wilayah Desa Raporendu sebagai berikut:

- Sebelah Utara

- Sebelah selatan

- Sebelah Timur

- Sebelah Barat
: Desa Tanazozo

: Kecamatan Pulau Ende

: Desa Bheramari

: Desa Nggorea

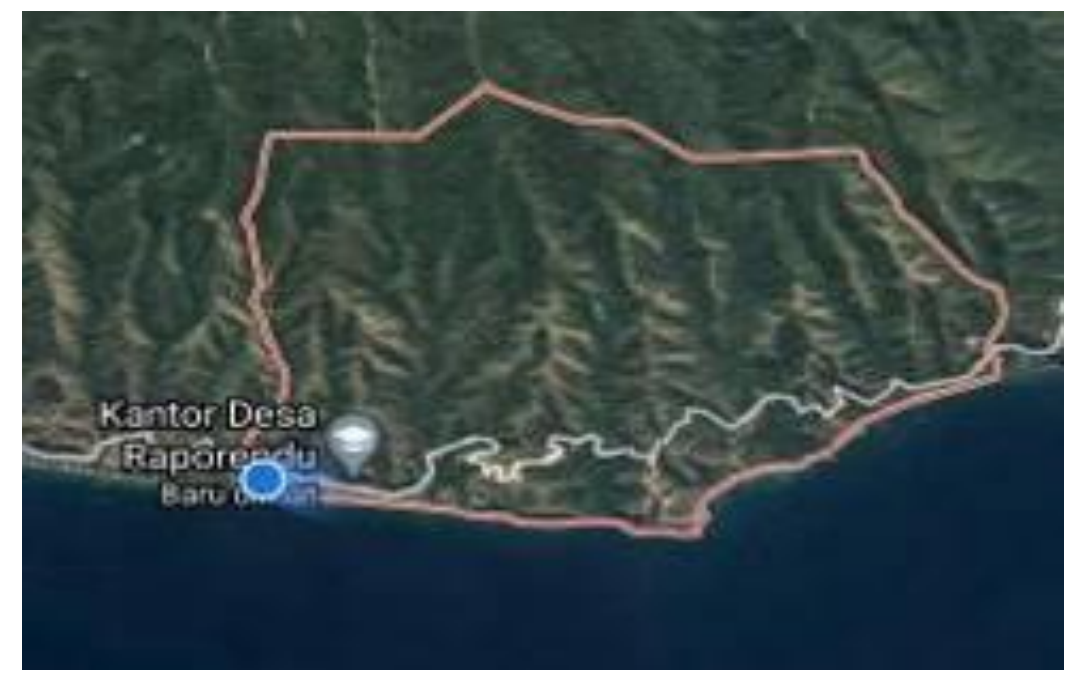

Gambar 1. Lokasi Desa Raporendu

Jumlah Kepala Keluarga di Desa Raporendu ada 633 KK dengan jumlah penduduk \pm 2.085 jiwa, terdiri dari laki-laki 982 jiwa dan perempuan 1.103 jiwa. Didesa ini terdapat 5 masjid, 1 Puskesmas pembantu, beberapa sekolah mulai dari Pendidikan Anak Usia Dini (PAUD) sampai Sekolah Menengah Pertama (SMP). Berdasarkan hasil survey pendahuluan dilokasi yaitu belum adanya wastafel atau tempat cuci tangan yang permanen di kantor desa sebagai salah satu usaha utuk mengurangi penyebaran Covid-19. Juga minimnya tempat sampah, sehingga banyak sampah berserakan atau dibuang ke laut yang bisa merusak lingkungan dan ekosistem yang ada di laut. Untuk mengatasi masalah tersebut, maka dilakukan pengabdian masyarakat melalui KKN mandiri 2021, dengan membuat wastafel dan bak sampah. Serta membersihkan rumah ibadah, membersihkan lingkungan desa dan membuat gapura dalam rangka peringatan Ulang Tahun ke-76 Republik Indonesia. 


\section{Metode Pelaksanaan}

Metode pelaksanaan yang dilakukan dalam kegiatan pengabdian ini adalah dengan survei langsung dilokasi KKN dan melakukan wawancara dengan Kepala Desa dan masyarakat setempat. Kemudian mahasiswa dan Dosen Pembimbing Lapangan (DPL) berdiskusi secara daring, diperoleh data apa saja yang diperlukan dan bagaimana proses kerjanya. Wastafel dan bak sampah dibuat yang permanen, bertujuan agar tidak mudah rusak atau berpindah tempat sehingga umur pakainya lebih lama. Maka untuk bahan dasar wastafel dibuat dari campuran semen, bak sampah dari susunan batako, dan gapura dari bahan bambu lokal. Semuanya dikerjakan bersamasama selama satu bulan masa KKN, sambil membantu kegiatan lain di kantor desa antara lain kerja bakti membersihkan desa, membantu admnistrasi guna persiapan pemekaran Desa Rendu Rua.

\section{Hasil dan Pembahasan}

Kegiatan KKN Mandiri ini dilaksanakan pada tahun ajaran Semester Genap 2020/2021. Sebelum mahasiswa turun ke lokasi, terlebih dahulu diberikan pembekalan dan arahan oleh panitia KKN Universitas Flores mengenai apa saja yang akan mereka lakukan selama masa KKN. Konsultasi dan proses pembimbingan mahasiswa oleh DPL dilakukan secara daring menggunakan beberapa aplikasi. Selama dilokasi, daftar hadir dan kegiatan setiap minggu dilaporkan secara online melalui e-learning dalam bentuk word/pdf dan link YouTube yang berisikan foto/video kegiatan (Wolo et al., 2020). Juga dibuatkan WhatsApp (WA) Group sebagai wadah komunikasi untuk mempercepat dalam berbagi informasi. Sehingga DPL dan panitia KKN, lebih mudah untuk mengecek dan memberi arahan kepada mahasiswa yang berada dilokasi berbeda-beda. Berikut adalah hasil kegiatan yang dilakukan selama KKN di Desa Raporendu

\section{1) Wastafel Permanen di Depan Kantor Desa Raporendu}

Pada masa era new normal ini masyarakat diharuskan untuk mengikuti protokol kesehatan yang ditetapkan pemerintah seperti mencuci tangan dan menggunakan masker (Oktaviola, 2021). Tidak terkecuali dengan masyarakat di Desa Roperandu, mencuci tangan adalah hal wajib yang dilakukan untuk mengurangi penyebaran virus. Tempat cuci tangan yang sudah ada di depan kantor desa, daya tampung volume air sedikit dan penempatannya kurang menarik sehingga perlu dibuat dan ditata kembali. Pembuatan westafel yang baru dibuat permanen dari bahan semen, bertujuan agar dapat digunakan dalam jangka waktu yang lama dan tidak mudah rusak. Ukuran kolom wastafel adalah $30 \mathrm{~cm} \times 30 \mathrm{~cm} \times 110 \mathrm{~cm}$, dan wadah diameter $40 \mathrm{~cm} \times$ tinggi $10 \mathrm{~cm}$. Sumber air yang digunakan langsung diambil dari jaringan pipa PDAM, sehingga tidak perlu menyediakan penampungan air dan cukup membuka keran. Dengan adanya wastafel ini, diharapkan agar masyarakat yang berkunjung dan perangkat desa di Kantor Desa Raporendu dapat menerapkan protokol kesehatan dengan selalu mencuci tangan untuk menekan penyebaran Covid-19 (Rangki et al., 2020). 

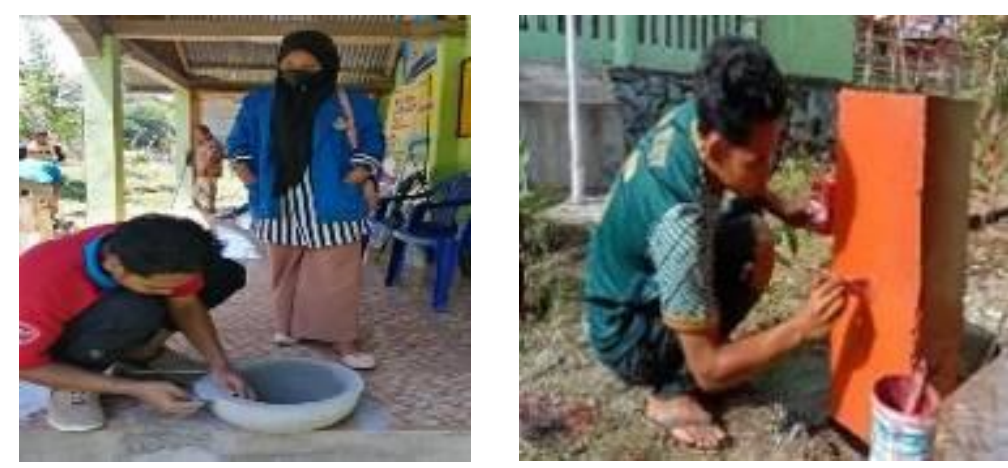

Gambar 2. Proses pembuatan wastafel
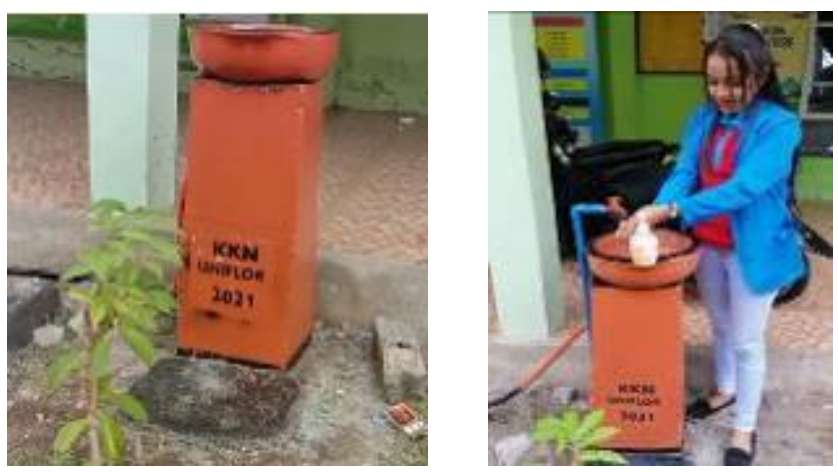

Gambar 3. Wastafel siap digunakan

2) Bak Sampah Permanen dari Bahan Batako

Sampah dipengaruhi oleh aktifitas manusia dan konsumsinya, seberapa banyak sampah yang dihasilkan akan memiliki dampak bagi sekitar baik dari segi kesehatan, keindahan dan kenyamanan (Mulasari et al., 2018). Kebersihan lingkungan dimulai dari menjaga kebersihan halaman dan selokan, dan membersihkan jalan di depan rumah dari sampah. Kebiasaan membuang sampah ke saluran drainase, laut atau membakar sampah di perkarangan rumah akan memberikan dampak negatif (Wahyuningsih et al., 2018). Banyak dampak negatif dari sampah yang dibuang tiidak pada tempatnya yaitu: akan mengakibatkan kebanjiran, sampah-sampah akan menyumbat saluran parit yang juga akan membuat banjir, akan menimbulkan bau busuk yang akan menimbulkan ketidaknyamanan pada warga sekitar (Riswan Hanafyah Harahap (McRizzwan), 2019). Hidup bersih dan sehat sendiri merupakan suatu hal yang seharusnya memang diterapkan dalam kehidupan sehari-hari oleh masyarakat sebagai salah satu cara menjaga kesehatannya. Mengingat kesehatan merupakan hal penting bagi setiap manusia mulai dari konsentrasi dalam bekerja dan beraktivitas dalam kehidupan sehari-hari (Ayu et al., 2018). Sekitar lokasi kantor desa belum ada tempat sampah permanen yang dapat menampung dengan volume yang lebih besar. Maka dibuatkan bak sampah dari susunan batako agar kuat dan tahan lama dengan ukuran panjang $130 \mathrm{~cm}$ $\mathrm{x}$ lebar $130 \mathrm{~cm} \times$ tinggi $100 \mathrm{~cm}$. Tujuan pembuatan bak sampah ini adalah untuk meminimalisir penumpukan sampah di pinggir jalan dan mampu menyadarkan masyarakat akan pentingnya menerapkan perilaku hidup 
bersih dan sehat untuk menjaga serta mencegah terjadinya pencemaran lingkungan. Dipilih bahan batako karena terbuat dari campuran semen dan pasir sehingga kuat dan tahan lama. Juga bentuknya yang beraturan, maka lebih mudah dalam pemasangan dan hasilnya rapi (Nita Hidayati, 2021). Proses pembuatannya tidak rumit, batako dicetak sendiri oleh mahasiswa dengan bantuan beberapa masyarakat setempat. Setelah dicetak, batako dikeringkan dalam waktu beberapa hari sampai mengeras dan siap digunakan. Kemudian batako disusun sesuai ukuran bak sampah yang telah direncanakan sebelumnya. Setelah batako tersusun maka dilakukan pekerjaan plesteran sisi dalam dan luar bak, kemudian terakhir pengecatan bagian luar bak dan siap digunakan untuk menampung sampah.
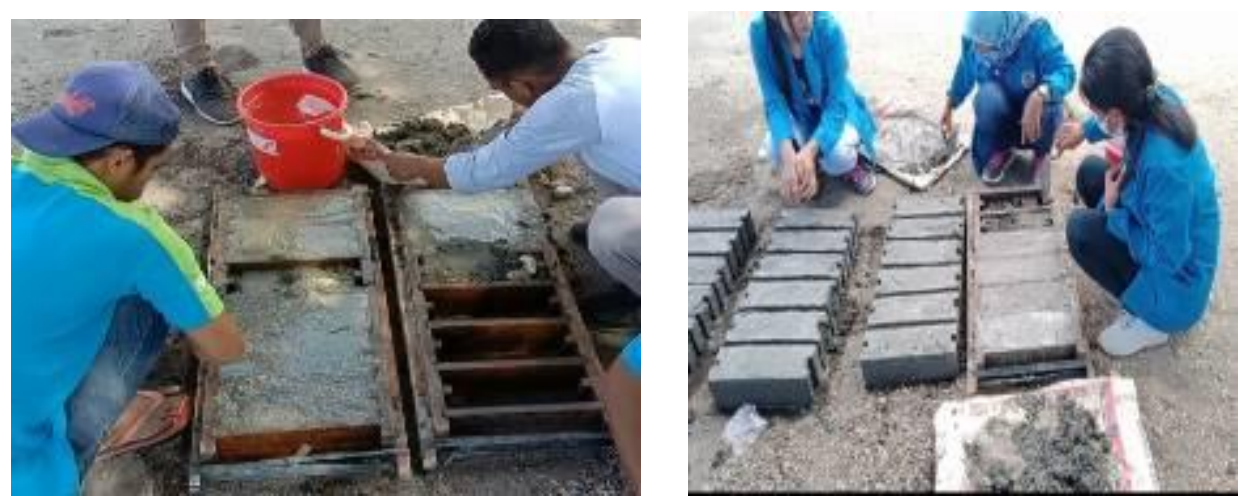

Gambar 4. Proses pencetakan batako
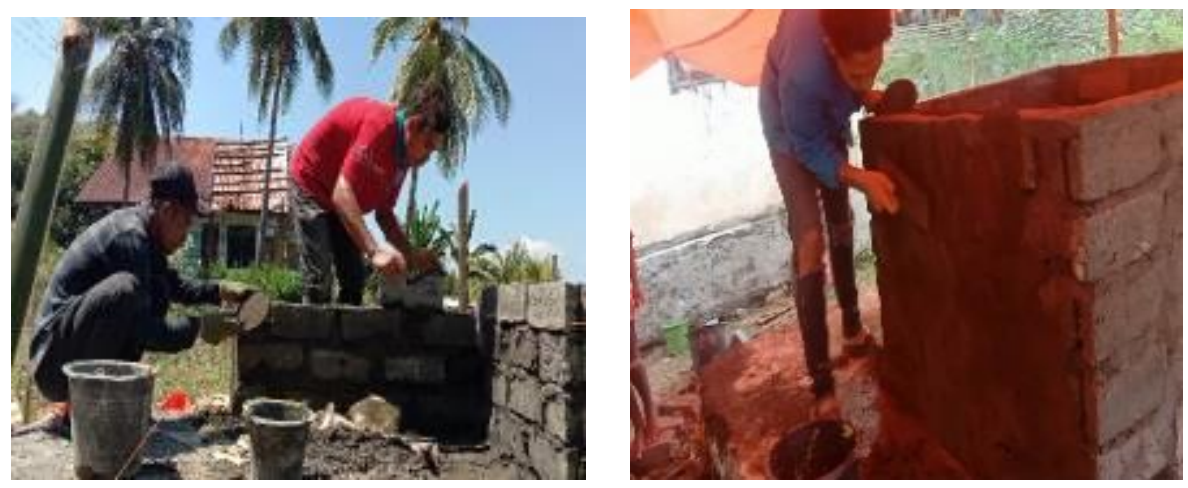

Gambar 5. Proses penyusunan batako dan plesteran
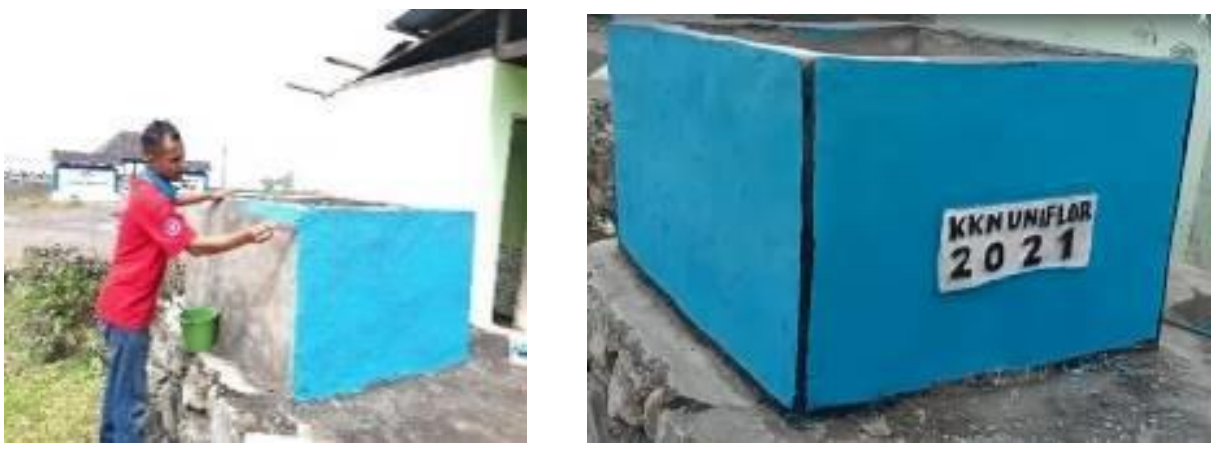

Gambar 6. Pengecatan luar bak dan siap digunakan 
3) Memperbaiki Instalasi Listrik di Dermaga Raporendu

Membantu Kepala Desa memperbaiki instalasi listrik yang rusak di Dermaga Pantai Raporendu, agar dapat berfungsi kembali seperti sediakala. Perlu dilakukan pemeriksaan jaringan listrik secara berkala agar lampulampu dapat berfungsi dengan baik, juga mencegah terjadinya kerusakan dan kehilangan karena pencurian.
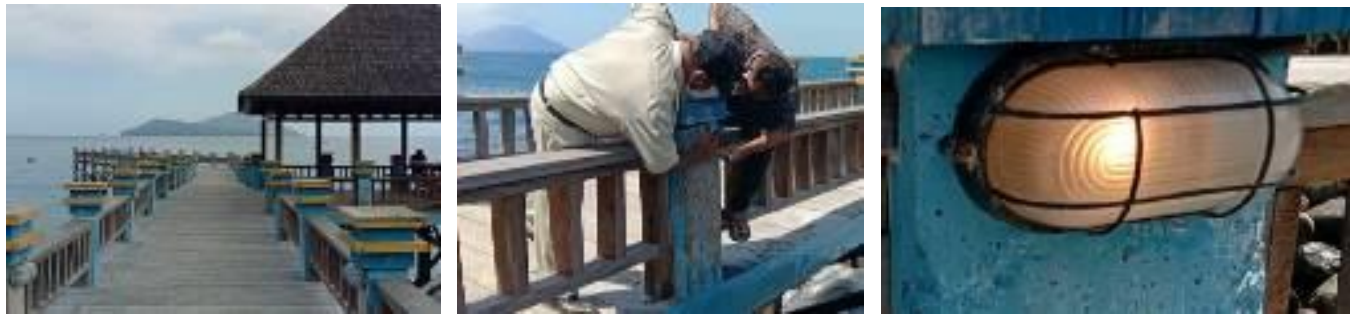

Gambar 7. Perbaikan jaringan listrik di Dermaga Raporendu

4) Gapura dari Bahan Bambu Lokal

Wilayah Desa Raporendu masih terjaga keasriannya, terlihat dari masih banyaknya rumpun bambu yang tumbuh subur dan rimbun. Bertepatan dengan Hari Kemerdekaan Republik Indonesia yang ke-76, dengan memanfaatkan bambu lokal di desa ini maka dibuatlah gapura sebagai pintu gerbang Kantor Desa Raporendu yang sebelumnya belum memiliki gapura. Dibantu masyarakat setempat, bambu ditebang dan diangkat ke kantor desa agar lebih mudah pengerjaannya dan bisa membantu pekerjaan lainnya. Setelah bambu ditebang, kemudian dibelah sesuai dengan ukuran yang dikehendaki serta dibentuk dan disusun menjadi gapura. Kemudian untuk memberi kesan menarik, dicat dengan warna merah putih identik sesuai dengan bendera Negara Indonesia. Meskipun tahun 2021 ini tidak mengadakan upacara peringatan Hari Kemerdekaan RI yang diperingati setiap tanggal 17 Agustus, tidak menyurutkan niat untuk tetap berkreativitas membuat gapura seperti yang biasa dilakukan sebelum masa pandemi.
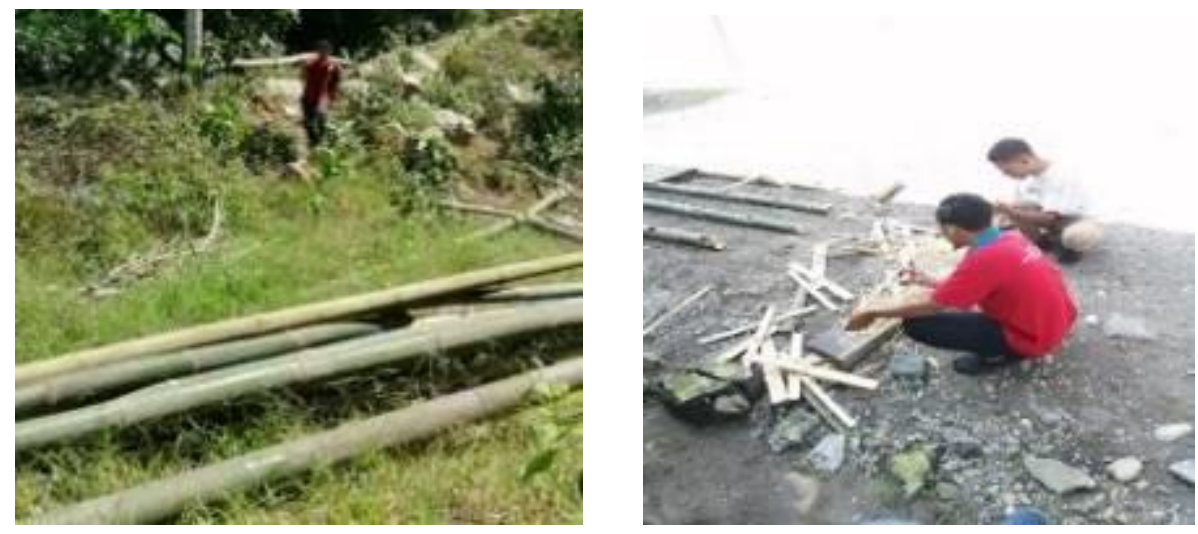

Gambar 8. Bambu lokal di ambil dan potong sesuai ukuran yang direncanakan 

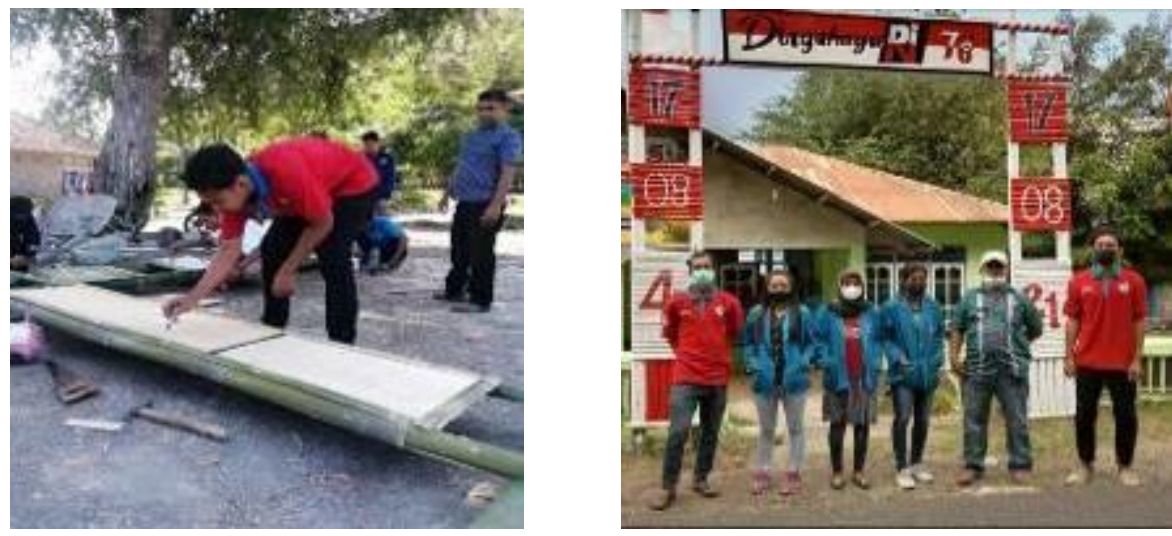

Gambar 9. Potongan bambu dirakit dan tampak depan gapura

5) Kerja Bakti Membersihkan Rumah Ibadat dan Lingkungan Desa

Warga Desa Raporendu seluruhnya menganut agama Islam, di desa ini memiliki 5 masjid sebagai rumah ibadat. Untuk menjaga kebersihan dan membantu penjaga masjid, setiap pagi sebelum waktunya sholat jumat dilakukan pembersihan masjid, baik bagian dalam maupun luar agar warga yang datang untuk beribadah merasa nyaman dan senang. Mahasiswa dan beberapa masyarakat juga membantu membersihkan lingkungan desa, agar bersih dari sampah-sampah yang berserakan dan rumput liar yang tumbuh disekitar kantor desa.
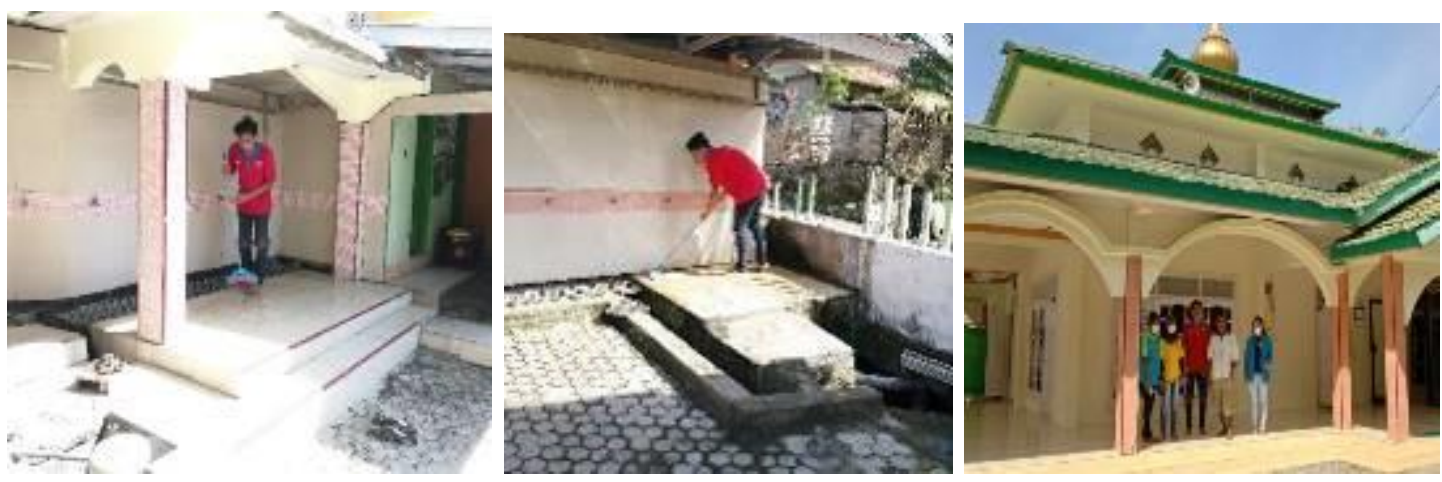

Gambar 10. Membersihkan Masjid Khaliq Mardiyah Basa
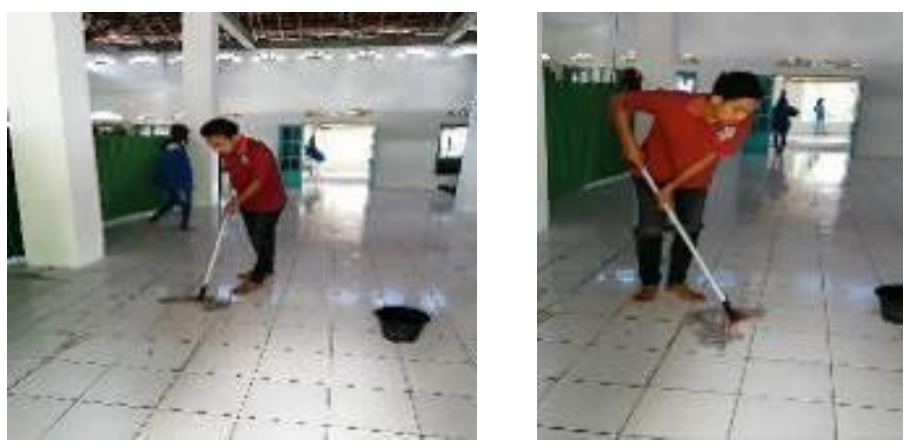

Gambar 11. Membersihkan Masjid Al-Amin 

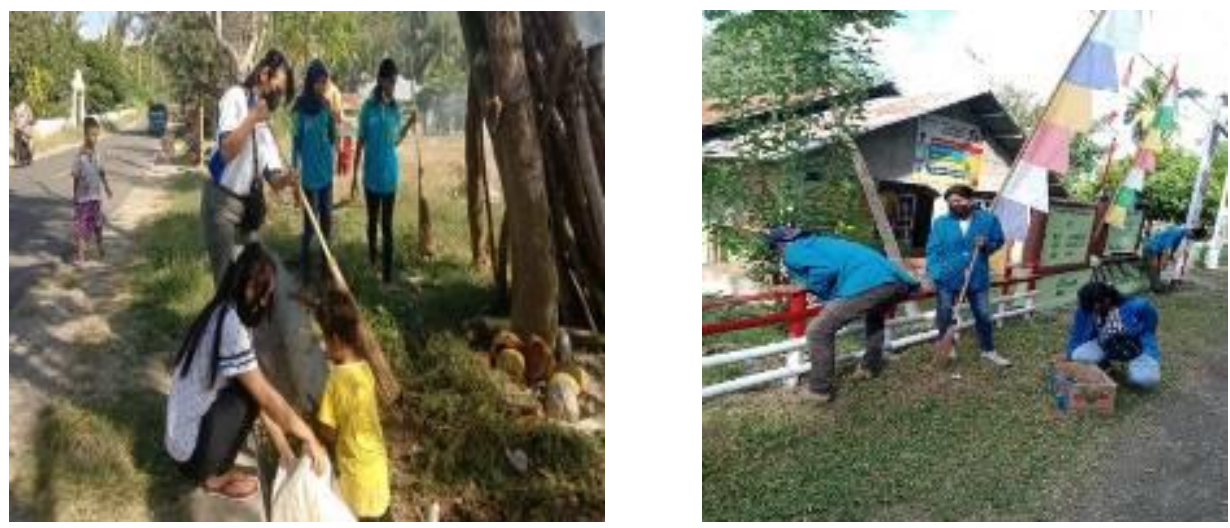

Gambar 12. Kerja bakti membersihkan lingkungan desa

6) Membantu Administrasi dan Persiapan Pemekaran Desa

Bersama Pemerintah Desa Raporendu dan masyrakat setempat, mengikuti kegiatan kunjungan tim verifikasi dari Kabupaten Ende untuk pemekaran desa persiapan Rendu Rua. Dilakukan beberapa persiapan menyambut tim verifikasi baik membantu staf pemerintah desa untuk membuat surat undangan, membersihkan lingkungan desa, dan turut berpartisipasi saat kedatangan tim verifikasi dilokasi.
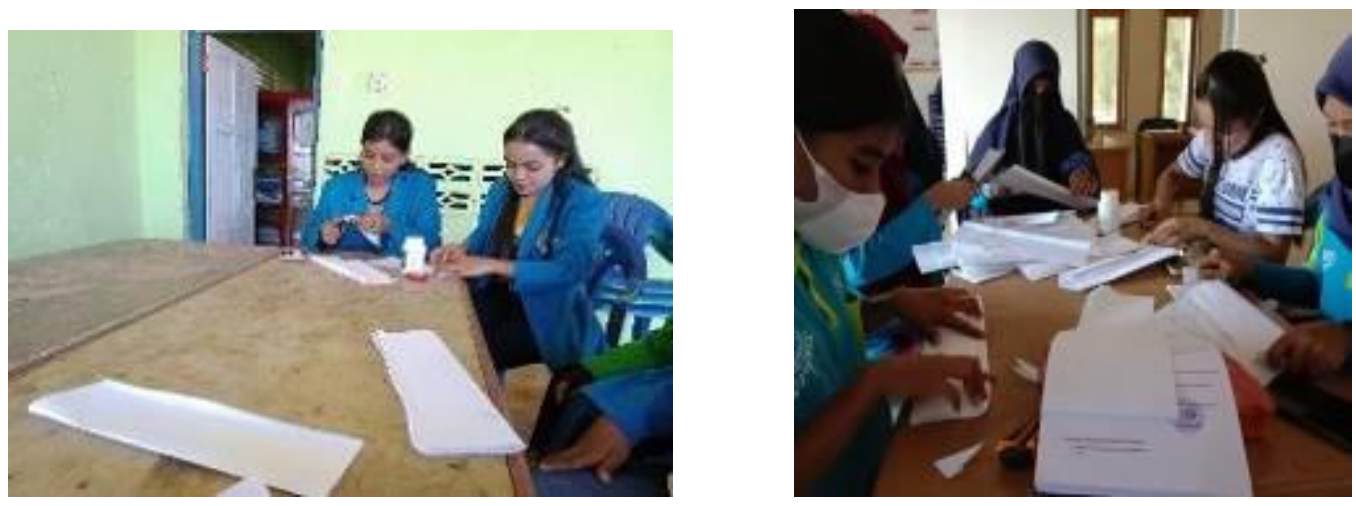

Gambar 13. Membantu proses administrasi
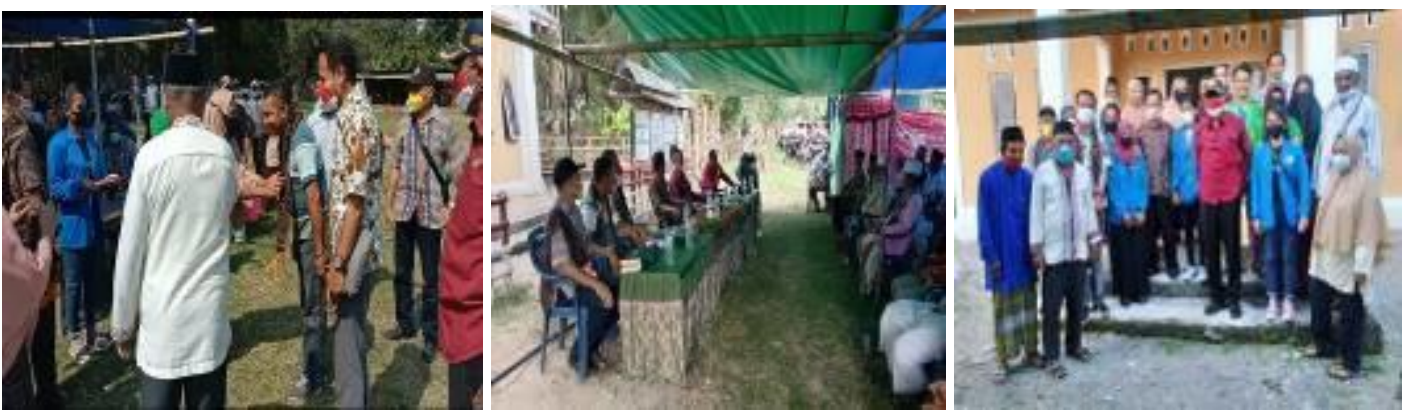

Gambar 14. Kunjungan tim verifikasi guna pemekaran desa 


\section{Simpulan dan Tindak Lanjut}

Kegiatan pengabdian masyarakat melalui KKN mandiri 2021 ini, memberi dampak positif bagi masyarakat dan Pemerintah Desa Raporendu. Wastafel permanen yang dibuat didepan Kantor Desa, mengingatkan kesadaran untuk mencuci tangan sebagai upaya menekan penyebaran Covid-19. Dengan dibuatnya bak sampah permanen, maka membuang sampah harus pada tempatnya guna mengurangi pencemaran lingkungan baik di sekitar kantor desa maupun di laut. Gapura dari bahan bambu lokal yang diletakkan di depan kantor desa, membuat tampak lebih menarik dalam memeriahkan Hari Kemerdekaan Indonesia ke-76. Melakukan kerja bakti di lingkungan desa dan beberapa masjid, membuat lebih bersih dan nyaman untuk beraktifitas dan beribadah. Diharapkan kerjasama Universitas Flores dan Desa Raporendu dalam bentuk kegiatan $\mathrm{KKN} /$ pengabdian masyarakat dapat terus berjalan setiap tahunnya, sehingga dapat membantu desa melalui program kerja lainnya.

\section{Daftar Pustaka}

Ayu, S. M., Kurniawan, A., Ahsan, A. Y., \& Anam, A. K. (2018). Peningkatan Kesehatan Melalui Perilaku Hidup Bersih Dan Sehat (Phbs) Sejak Dini Di Desa Hargomulyo Gedangsari Gunung Kidul. Jurnal Pemberdayaan: Publikasi Hasil Pengabdian Kepada Masyarakat, 2(1), 20. https://doi.org/10.12928/jp.v2i1.437

Heydemans, N. A., Lombogia, R., Siwu, I. C., \& Kenang, R. C. P. (2021). Kegiatan Kuliah Kerja Nyata di Masa Pandemi Covid-19. 2(1), 31-40.

Mulasari, S. A., Sulistyawati, S., Sukesi, T. W., \& Tentama, F. (2018). Pembinaan Bank Sampah K3S Jatikuning. Jurnal Pemberdayaan: Publikasi Hasil Pengabdian Kepada Masyarakat, 2(2), 283. https://doi.org/10.12928/jp.v2i2.411

Nita Hidayati. (2021). 8 Kelebihan Dan Kekurangan Batako Sebagai Bahan Bangunan. Perhatikan Sebelum Pakai! Www.99.Co. hhttps://www.99.co/blog/indonesia/kelebihan-dan-kekurangan-batako/

Oktaviola, R. D. (2021). Kuliah Kerja Nyata (KKN) tematik membudayakan hidup sehat bagi anak-anak untuk mencegah penyebaran Covid-19 di Desa Ngliman Kecamatan Sawahan Kabupaten Nganjuk. 4(1). http://ejournal.uniramalang.ac.id/attamkin/ Volume 4 No. 1Mei 2021

Rangki, L., Alifariki, L. O., \& Dalla, F. (2020). Upaya pencegahan dan penanggulangan transmisi covid 19 melalui program KKN Tematik Mahasiswa Universitas Halu Oleo. Journal of Community Engagement in Health, 3(2), 266-274. http://jceh.org/

Riswan Hanafyah Harahap (McRizzwan). (2019). Cara Menjaga Lingkungan Tetap Bersih. Https://Disperkimta.Bulelengkab.Go.Id/. isperkimta.bulelengkab.go.id/informasi/detail/artikel/cara-menjaga- 
lingkungan-tetap-bersih-23

Umar, A. U. A. Al, Savitri, A. S. N., Pradani, Y. S., Mutohat, \& Khamid, N. (2021). Peranan Kuliah Kerja Nyata Sebagai Wujud Pengabdian Kepada Masyarakat Di Tengah Pandemi COVID-19. E-Amal Jurnal Pengabdian Kepada Masyarakat, 1(1), 39-47. www.journal.uta45jakarta.ac.id

Wahyuningsih, I. R., Bakti, A. S., Fransisca, I. R., \& Oktavia, H. S. (2018). Pemberdayaan Masyarakat Dusun Jodog, Karangasem, Kadisoro, Desa Gilangharjo, Pandak, Bantul Dalam Pengolahan Sampah. Jurnal Pemberdayaan: Publikasi Hasil Pengabdian Kepada Masyarakat, 2(3), 519. https://doi.org/10.12928/jp.v2i3.540

Wolo, D., Ngapa, Y. S. D., \& Harıyanti, M. L. (2020). Pengabdian KKN-Mandiri Desa Golo Wuas Kabupaten Manggarai Timur. Mitra Mahajana: Jurnal Pengabdian Masyarakat, $1(1), \quad 24-31$. https://doi.org/10.37478/mahajana.v1i1.715 